\section{Growing Environmental Stewards: The Overall Effect of a School Gardening Program on Environmental Attitudes and Environmental Locus of Control of Different Demographic Groups of Elementary School Children}

\author{
O.M. Aguilar ${ }^{1}$, T.M. Waliczek², and J.M. Zajicek ${ }^{3,4}$
}

\begin{abstract}
AdDitional INDEX WORDS. environmental education, integrated education, experiential education

Summary. The objectives of this study were to examine an interdisciplinary and experiential approach to environmental education by use of a youth gardening program for third through fifth grade students. In addition, this study evaluated the gardening program's effectiveness on promoting positive environmental attitudes and a high environmental locus of control with children. A questionnaire was developed from three existing instruments and was used to collect information concerning environmental attitudes, locus of control as it related to environmental actions, and demographic information of respondents. No statistically significant differences were found on either variable in comparisons of experimental and control group responses. However, students from both groups exhibited positive environmental attitudes. Demographic comparisons indicated that children with previous gardening experience scored significantly higher on the environmental attitude and environmental locus of control statements when compared with children without gardening experience. Girls scored significantly higher than boys on environmental attitude and environmental locus of control scores. Caucasians scored significantly higher when compared with African-Americans and Hispanics on environmental attitude scores, and Caucasians scored significantly higher when compared with African-Americans on environmental locus of control scores.
\end{abstract}

S ince the inception of Earth Day on 20 Apr. 1970, environmental awareness has been recognized as an issue to be taken seriously and one that will not disappear. Even before that, in 1962, Rachel Carson's Silent Spring stirred some people to take notice of the damage being done to the environment (Carson, 1962; Krause, 1993). In the early 1970s, air, water, and land pollution became more than just unsightly; people became more concerned with human health threats and threats to other necessary resources (Howell and Warmbrod, 1974; Krause, 1993).

Advances in technology were one of the first methods used in combating some environmental crises

\footnotetext{
${ }^{1}$ Graduate Assistant, Department of Horticultural Sciences, Texas A\&M University, College Station, TX 77843-2133

${ }^{2}$ Associate Professor, Department of Agriculture, Texas State University, San Marcos, TX 78666

${ }^{3}$ Professor, Department of Horticultural Sciences, Texas A\&M University, College Station, TX 778432133

${ }^{4}$ Corresponding author. E-mail: j-zajicek@tamu.edu.
}

(Newhouse, 1991). People quickly realized, however, that to prevent further damage to the natural ecosystem, it would be necessary to produce tious decisions regarding the environment (Culen et al., 1986; Gigliotti, 1992; Hungerford and Volk, 1990). Environmental knowledge, environmental attitudes, environmental locus of control, and a sense of responsibility were elements deemed critical to producing responsible environmental citizens (Hines et al., 1987; Newhouse, 1991; Ramsey, 1993). Environmental knowledge and attitudes would lead to a person being knowledgeable about environmental facts and issues and having a respect for nature. A high environmental locus of control would lead to a person believing in his/her ability to make a difference and acting responsibly regarding those environmental issues, as well as that person becoming more inclined to be environmentally proactive (Hines et al., 1987; Newhouse, 1991; Ramsey, 1993). environmental stewards capable of making knowledgeable and conscien-
An internal locus of control is an individual's belief that he/she caused the outcome of a certain event, whereas an external locus of control is the belief that others caused the outcome of an event.

With the realization that human influences have a greater impact on the environment than do technological advances came the emergence of environmental programs in government sectors, nonprofit organizations, and public schools to improve the environmental actions of citizens (Howell and Warmbrod, 1974; Knapp, 1972; Ravitch, 2000). Thus, "environmental education" became part of the classroom curriculum for many schools.

Unfortunately, some educators felt that there were impediments to implementing environmental education into a classroom curriculum such as a lack of resources, funding, and time (Disenger, 1998; Ham and Sewing, 1987; Ramsey, 1997). Another stumbling block was the teachers' lack of information and ideas on how to integrate environmental education into the classroom curriculum. Teachers seemed to associate environmental education only within the context of the science curriculum (Ham and Sewing, 1987), although environmental education can be covered in a diverse range of subjects (Lieberman and Hoody, 1998). In fact, some studies suggested that environmental education was most effective when integrated into all classroom subjects and not simply focused in just one subject area or at one grade level (Ham et al., 1987; Lieberman and Hoody, 1998; Ramsey et al., 1992; Skelly and Zajicek, 1998; Wilson and Smith, 1996).

Additionally, environmental education has been easily incorporated into hands-on experiences. Many notable educational philosophers, including Dewey, believed that experience was the starting point of all learning (Dewey, 1938; Ornstein and Hunkins, 1998; Ravitch, 2000), and promoted this type of experiential education. Environmental education provided children with the opportunity to practice responsible environmental actions, which helped them to develop new environmental behaviors (Dressner and Gill, 1994; Hudson, 2001).

In addition to the barriers environmental educators have been faced 
with, the children they are trying to reach live in an industrialized environment that often offers little chance for direct contact with natural ecosystems (Hudson, 2001). Children in this society often have to depend on secondary sources such as television shows and educators to learn about ecology and their natural surroundings (Cohen and Horm-Wingerd, 1993; Knapp, 1972). Many children lack a personal intimacy with the environment that would enable them to have a true understanding of common environmental problems (Hart, 1977; Hudson, 2001).

The interaction of children with nature in a garden may be one solution. The use of a garden in the classroom setting provides the right experience for children needing to learn about their natural environment (Pale et al., 2001; Waliczek and Zajicek, 1999). Not only can a garden and gardening act activities enable students to learn about the environment, but also children can actually experience ecological processes firsthand. In addition, a gardening-based curriculum can cover a wide range of classroom subjects while giving the students a glance at nature on a more personal level (Eames-Sheavly, 1994; Klemmer et al., 2005; Pigg et al., 2006; Skelly and Zajicek, 1998).

The purpose of this study was to examine an interdisciplinary and experiential approach to environmental education by use of a youth gardening program for third through fifth grade students and to evaluate the gardening program's effectiveness on promoting positive environmental attitudes and a high environmental locus of control with children.

\section{Materials and methods}

Educational CURriculum. The youth gardening program that was used for the study was the Junior Master Gardener Handbook Level 1 developed for grades 3 through 5 (Texas Cooperative Extension Service, 1999). The program curriculum was comprised of eight chapters relating to horticulture and environmental education, including plant growth and development, soils and water, ecology and environmental horticulture, insects and disease, landscape horticulture, fruits and nuts, vegetables and herbs, and life skills and career exploration. Each chapter contained objectives and numerous activities with detailed instructions. The activities were developed to occur in a variety of settings, including the classroom or outside in the garden.

For the purpose of this study, all experimental groups were required to use activities from the youth gardening curriculum. However, the number of activities and the subject matter of the activities in which each experimental class participated were left to the discretion of the individual teachers. Therefore, the treatment varied from class to class within the experimental group. Control groups from this study continued with their regular classroom activities and did not participate in any youth gardening program activities within the school setting during the school year.

SAMPLE. This study was conducted with the cooperation of elementary schools from the Temple Independent School District (TISD) in Temple, Texas. At the time of the study, the TISD was composed of $46 \%$ Caucasians, $28 \%$ AfricanAmericans, 24\% Hispanics, and 2\% Asian-Americans. Fifty percent of the students in the school district were considered to be of a low socioeconomic status, based on the U.S. Department of Agriculture guidelines for free or reduced price lunches. Third through fifth graders from seven of the nine elementary schools in TISD participated in this study. Teachers volunteered their classes into the experimental or control group. A total of 654 third through fifth grade students were included in the study: 461 students participated in the experimental group and 193 participated in the control group. Teachers were asked to administer the environmental attitude and environmental locus of control questionnaires at the end of the school year.

InSTRUMENTATION. Segments from three different testing instruments were adapted and used to determine the environmental attitudes and environmental locus of control of the participants. The questionnaire was created using existing instruments, drawing questions from the Children's Environmental Response Inventory (CERI; Bunting and Cousins, 1983), an environmental attitude inventory (Cammack et al., 2002a) and the Revised Perceived Environ- mental Control Measure (RPECM; Smith-Sebasto, 1992). A demographic questionnaire for students was included as a cover sheet.

CERI in its original format consisted of nine categories used to assess children's environmental personalities, including pastoralism, urbanism, environmental adaptation, stimulus seeking, environmental trust, antiquarianism, need privacy, mechanical orientation, and communality (Bunting and Cousins, 1983). The entire test consisted of 185 statements. Because of the length of the test and irrelevancy of some of the categories for the purpose of this study, only 15 statements from two categories, pastoralism and environmental adaptation, were used. Bunting and Cousins (1983) described pastoralism as how one enjoys the natural environment intellectually and aesthetically. Environmental adaptation was described as the belief that human rights to technology are justified in the domination of nature.

Questions from an environmental attitude inventory (Cammack et al., 2002a) were also used in the development of the research questionnaire. The original test from which questions were drawn included 10 statements. Six of the 10 statements were used for this study because they presented clear, straightforward statements about attitudes toward nature and animals, and environmental actions.

To measure environmental locus of control, statements from the RPECM (Smith-Sebasto, 1992) were adapted. These statements reflected the respondent's belief that he/she caused the outcome of a certain event or that other people caused the outcome of that event (Smith-Sebasto, 1992). The original format consisted of 45 environmental locus of control statements. The statements were divided into five different environmental action categories: ecomanagement, legal action, consumer action, persuasion, and political action. For this study, statements from the ecomanagement and persuasion sections of the original instrument were used because they were most suited for elementary-aged children.

All of the statements used were analyzed and modified if necessary to suit third grade comprehension and reading levels. Third grade teachers 
and environmental education professionals reviewed the questions to ensure ease of comprehension and validity of the instrument. The final survey consisted of 28 statements. Twenty of these statements concerned environmental attitudes, and eight statements corresponded to environmental locus of control. All questions were asked using the same Likert-type scale (Likert, 1967). For each statement, there were five possible answers: "agree very much," "agree," "don't know/don't care," "disagree," and "disagree very much." Statements were presented in positive and negative connotations to ensure consistent and reliable responses among participants. A Cronbach's alpha test indicated the reliability of the final environmental attitude and environmental locus of control questionnaire to be 0.85 , which is sufficiently reliable for research purposes (Gall et al., 1996).

When scoring the instrument, it was necessary to re-code answers so that the least favorable response received zero points and the most favorable response received four points. With 20 questions asked, the highest score possible for the environmental attitude section was 80 points. A score of 44 points or higher was determined to indicate positive environmental attitudes because this was well above the median and neutral score of 40 . With eight questions asked, the highest score possible for the environmental locus of control section was 32 points. A score of 18 or more indicated a higher environmental locus of control because it was well above the median and neutral score of 16 .

Demographic information was collected from the participants on the cover sheet of the questionnaire. Questions asked respondents to provide information pertaining to ethnicity, gender, age, place of residence, and previous gardening knowledge or experience.

Data analysis. The data collected from the post-tests of the experimental and control groups were compared using analysis of variance (ANOVA), multivariate ANOVA, and $t$ tests to expose any differences between scores. The analysis was conducted using SPSS (release 10.0 for Windows; SPSS, Chicago).

\section{Results and discussion}

EnVironmental atTitude scores. After performing a paired $t$ test, it was determined that there were no statistically significant differences in environmental attitude scores between the experimental group and the control group (Table 1). Scores on this section of the questionnaire ranged from 31 to 80 with a possible range of 0 to 80 . Overall, scores from both groups were well above the predetermined positive environmental attitude score of 44 . The lack of differences in control and experimental groups supports previous studies by Skelly and Zajicek (1998), Leeming et al. (1997), and Jaus (1982). Environmental education has gained significant momentum in the past years, entering schools and homes in greater strides (Hudson, 2001; Palmberg and Kuru, 2000; Shin, 2000; Waliczek and Zajicek, 1999), perhaps explaining the positive environmental attitude scores of experimental and control groups.

LOCUS OF CONTROL SCORES. No statistically significant differences were found in comparisons of environmental locus of control scores of the experimental and control groups (Table 1). The mean score for the experimental group was 21.69 and the mean score for the control group was 21.09 out of a possible 32 points. Locus of control of an individual has been found to be susceptible to alteration, especially when appropriate teaching techniques are practiced (Rowe, 1973). However, this program did not appear to influence the environmental locus of control of students.

Table 1. Paired-samples $t$ test comparing environmental attitude scores and environmental locus of control scores between experimental and control groups participating in the study of the effect of a youth gardening program on environmental attitudes and environmental locus of control of elementary school children.

\begin{tabular}{lcccccc}
\hline Group & $\begin{array}{c}\text { Sample size } \\
\text { (no.) }\end{array}$ & $\begin{array}{c}\text { Mean } \\
\text { score }\end{array}$ & SD & df & $\boldsymbol{t}$ & $\boldsymbol{P}$ \\
\hline Environmental attitude $^{\mathrm{z}}$ & & & & & & \\
$\quad$ Control & 193 & 57.25 & 9.87 & 652 & -0.139 & 0.890 \\
$\quad$ Experimental & 461 & 57.37 & 10.72 & & & \\
Locus of control $^{\mathrm{y}}$ & & & & & & \\
$\quad$ Control & 193 & 21.09 & 4.74 & 652 & -1.420 & 0.156 \\
$\quad$ Experimental & 461 & 21.69 & 5.07 & & & \\
\hline
\end{tabular}

${ }^{\mathrm{z}}$ Students received a raw score on the test instrument ranging from 0 to 80 based on their answers. Environmental attitude scores of 44 points or more indicated positive environmental attitudes.

${ }^{y}$ Students received a raw score on the test instrument ranging from 0 to 32 based on their answers. Locus of control scores of 18 points or more indicated a more internal environmental locus of control. 
Table 2. An ANOVA comparison of environmental attitude scores and environmental locus of control scores of male and female participants in the study of the effect of a youth gardening program on environmental attitudes and environmental locus of control of elementary school children.

\begin{tabular}{lrrrrrr}
\hline Gender & Sample size (no.) & Mean score & SD & df & t & $P$ \\
\hline \multicolumn{2}{l}{ Environmental attitude } \\
Girl & 347 & & & & & \\
Boy & 307 & 59.48 & 9.83 & 1 & 32.634 & $0.000^{*}$ \\
Total & 654 & 57.91 & 10.65 & & & \\
Locus of control & & & & & & \\
Girl & 347 & 22.47 & 4.81 & 1 & 28.428 & $0.000^{*}$ \\
Boy & 307 & 20.43 & 4.97 & & & \\
Total & 654 & & & & & \\
\hline
\end{tabular}

${ }^{\mathrm{z}}$ Students received a raw score on the test instrument ranging from 0 to 80 based on their answers. Environmental attitude scores of 44 points or more indicated positive environmental attitudes.

'Students received a raw score on the test instrument ranging from 0 to 32 based on their answers. Locus of control scores of 18 points or more indicated a more internal environmental locus of control.

* Statistically significant at $P \leq 0.05$.

Table 3. An ANOVA comparison of students of different ethnicities and their environmental attitude scores and environmental locus of control scores in the study of the effect of a youth gardening program on environmental attitudes and environmental locus of control of elementary school children.

\begin{tabular}{lrrrrrr}
\hline Ethnicity & $\begin{array}{c}\text { Sample } \\
\text { size (no.) }\end{array}$ & Mean score & SD & df & t & $\boldsymbol{P}$ \\
\hline Environmental attitude $^{z}$ & & & & & & \\
$\quad$ African-American & 169 & 53.69 & 10.00 & 4 & 11.103 & $0.000^{*}$ \\
Asian-American & 17 & 58.06 & 14.29 & & & \\
Caucasian & 257 & 60.26 & 9.80 & & & \\
Hispanic & 119 & 56.77 & 10.49 & & & \\
Other & 82 & 56.40 & 9.97 & & & \\
Total & 644 & 57.34 & 10.45 & & & \\
Locus of control & & & & & & \\
African-American & 169 & 19.87 & 5.11 & 4 & 8.373 & $0.000^{*}$ \\
Asian-American & 17 & 22.47 & 4.98 & & & \\
Caucasian & 257 & 22.62 & 4.43 & & & \\
Hispanic & 119 & 21.20 & 5.16 & & & \\
Other & 82 & 21.59 & 5.28 & & & \\
Total & 644 & 21.50 & 4.99 & & & \\
\hline
\end{tabular}

${ }^{2}$ Students received a raw score on the test instrument ranging from 0 to 80 based on their answers. Environmental attitude scores of 44 points or more indicated positive environmental attitudes.

'Students received a raw score on the test instrument ranging from 0 to 32 based on their answers. Locus of control scores of 18 points or more indicated a more internal environmental locus of control.

* Statistically significant at $P \leq 0.05$.

Table 4. An ANOVA comparison of environmental attitude scores and environmental locus of control scores of participants who had gardened versus those who had not gardened in the study of the effect of a youth gardening program on environmental attitudes and environmental locus of control of elementary school children.

\begin{tabular}{lrrrrrr}
\hline Garden experience & $\begin{array}{c}\text { Sample } \\
\text { size (no.) }\end{array}$ & $\begin{array}{l}\text { Mean } \\
\text { score }\end{array}$ & SD & df & t & $\boldsymbol{P}$ \\
\hline Environmental attitude $^{\mathrm{z}}$ & & & & & & \\
$\quad$ Yes & 556 & 58.25 & 10.02 & 1 & 27.160 & $0.000^{*}$ \\
$\quad$ No & 96 & 52.35 & 11.42 & & & \\
$\quad$ Total & 652 & 57.38 & 10.44 & & & \\
Locus of control & & & & & & \\
$\quad$ Yes & 556 & 21.48 & 4.88 & 1 & 14.581 & $0.000^{*}$ \\
$\quad$ No & 96 & 19.77 & 5.09 & & & \\
$\quad$ Total & 652 & 21.54 & 4.96 & & & \\
\hline
\end{tabular}

${ }^{\mathrm{z}}$ Students received a raw score on the test instrument ranging from 0 to 80 based on their answers. Environmental attitude scores of 44 points or more indicated positive environmental attitudes.

'Students received a raw score on the test instrument ranging from 0 to 32 based on their answers. Locus of control scores of 18 points or more indicated a more internal environmental locus of control.

* Statistically significant at $P \leq 0.05$.
Results from the study indicated that girls appeared to be more internally oriented in their environmental locus of control when compared with boys. This finding could be a result of the nature of the locus of control statements tested. All statements used concerned environmental actions to which girls have been shown to be more sensitive (Harvey, 1989; Waliczek and Zajicek, 1999).

ETHNICITy. Using a one-way ANOVA test, statistically significant differences were found between ethnic groups on environmental attitude and environmental locus of control scores (Table 3). Post hoc comparisons (Tukey's least significant difference) found statistically significant differences between environmental attitude scores of African-Americans and Caucasians, and between environmental attitude scores of Hispanics and Caucasians (Table 3). Caucasian students scored 6.57 points higher when compared with African-American students, and 3.49 points higher than Hispanic students. Post hoc comparisons also showed that Caucasians scored statistically significantly higher (2.75 points higher) on environmental locus of control scores when compared with African-Americans.

Past research has shown that minorities, especially African-Americans and Hispanics, typically have not scored as high as Caucasians on instruments measuring concern for the environment (Kellert, 1985; Sheppard, 1995; Waliczek and Zajicek, 1999), and that differences are sometimes tied to other variables that are interdependent with ethnicity such as socioeconomic status, education level, priority of needs, and level of acculturation (Caro and Ewert, 1995; Sheppard, 1995; Waliczek and Zajicek, 1999). Past research has also indicated that Caucasians have been known to perceive a more internal locus of control when compared with AfricanAmericans (Lefcourt, 1976).

PREVIOU S GARDENIN G EXPERIENCE. One survey question asked students if they had previous gardening experience. ANOVA test comparisons showed statistically significant differences between scores of those that had gardened and those that had not (Table 4). Students that had previous gardening experience scored 5.9 points higher on the 
environmental attitude statements and 2.07 points higher on environmental locus of control statements when compared with students without gardening experience.

These figures indicated that children that had any type of experience with gardening had more positive attitudes toward the environment and exhibited a more internal environmental locus of control when compared with students that had not gardened. A similar study by Skelly and Zajicek (1998) found that participation in outdoor activities was highly correlated to environmental attitudes. Researchers repeatedly have found that experiences with the environment at an early age contributed to children's relationships with and concern for the environment (Cohen and Horm-Wingerd, 1993; Harvey, 1989; Skelly and Zajicek, 1998).

Environmental locus of control scores were also statistically significantly higher for children who reported previous gardening experience. This finding implied that the experience of gardening increased a child's perceived internal locus of control. Gardening has been an activity that uses delayed gratification and problem solving through questioning, which were both effective practices that affect locus of control (Rowe, 1973). Gardening also required skillrelated work, which encouraged people to use personal experience in decision-making. This, in effect, encouraged people to focus on their own internal abilities (James and Rotter, 1958).

Additionally, results from this question indicated that $82.4 \%$ of students in the control group and $86.1 \%$ of students in the experimental group had had some type of experience gardening (Table 5 ). This figure might have influenced the previous analysis between the experimental and control groups, as both groups seem to be gardening in similar numbers.

\section{Conclusions}

Results from this study indicated that more than $80 \%$ of children in the study were involved in gardening to some extent, either within the classroom or through informal experiences at home, and that these past experiences appeared to have an effect on children's environmental attitudes

Table 5. Demographic breakdown of the control and experimental groups participating in the study of the effect of a youth gardening program on environmental attitudes and environmental locus of control of elementary school children.

\begin{tabular}{|c|c|c|c|c|}
\hline Demographic & $\begin{array}{c}\text { Control } \\
\text { (no.) }\end{array}$ & $\begin{array}{c}\text { Control } \\
(\%)\end{array}$ & $\begin{array}{c}\text { Experimental } \\
\text { (no.) }\end{array}$ & $\begin{array}{c}\text { Experimental } \\
(\%)\end{array}$ \\
\hline \multicolumn{5}{|l|}{ Gender } \\
\hline Girl & 97 & 50.3 & 250 & 54.2 \\
\hline Boy & 96 & 49.7 & 211 & 45.8 \\
\hline \multicolumn{5}{|l|}{ Age (years) } \\
\hline 8 & 14 & 7.3 & 18 & 3.9 \\
\hline 9 & 74 & 38.3 & 95 & 20.6 \\
\hline 10 & 52 & 26.9 & 177 & 38.4 \\
\hline 11 & 47 & 24.4 & 152 & 33.0 \\
\hline 12 & 4 & 2.1 & 11 & 2.4 \\
\hline \multicolumn{5}{|l|}{ Grade } \\
\hline 3 & 79 & 40.9 & 87 & 18.9 \\
\hline 4 & 55 & 28.5 & 203 & 44.0 \\
\hline 5 & 59 & 30.6 & 171 & 37.1 \\
\hline \multicolumn{5}{|l|}{ Ethnicity } \\
\hline \multicolumn{5}{|c|}{ African-American } \\
\hline 69 & 35.8 & 100 & 21.7 & \\
\hline \multicolumn{5}{|c|}{ Asian-American } \\
\hline 3 & 1.6 & 14 & 3.0 & \\
\hline \multicolumn{5}{|l|}{ Caucasian } \\
\hline 71 & 36.8 & 186 & 40.3 & \\
\hline \multicolumn{5}{|l|}{ Hispanic } \\
\hline 33 & 17.1 & 86 & 18.7 & \\
\hline \multicolumn{5}{|l|}{ Other } \\
\hline 16 & 8.3 & 66 & 14.3 & \\
\hline \multicolumn{5}{|l|}{ Residence } \\
\hline City & 162 & 83.9 & 410 & 88.9 \\
\hline Country & 27 & 14.0 & 48 & 10.4 \\
\hline \multicolumn{5}{|c|}{ Gardening experience } \\
\hline Yes & 159 & 82.4 & 397 & 86.1 \\
\hline No & 33 & 17.1 & 63 & 13.7 \\
\hline
\end{tabular}

and environmental locus of control. These results showed that exposure to hands-on gardening in any type of situation seemed to influence children in a positive way when considering the environmental variables of interest.

However, results from the study did not conclude that the youth gardening curriculum was influencing environmental attitudes or environmental locus of control of youngsters involved in the school gardening program. These results indicate that hands-on gardening activities are important to the development of environmentally concerned citizens, but that children involved may not need to be involved in formal school gardening curriculum activities to benefit in the area of environmental concern.

Past research has found that children benefit in many other ways from participating in formal gardening programs. These include improved science achievement (Klemmer et al., 2005), better nutrition (Lineberger and Zajicek, 2000), improved selfesteem and self-development (Cammack et al., 2002b), as well as patience and pride in their labors (Alexander et al., 1995).

Results from the study also found that there were gender and ethnicity differences among children, with girls and Caucasians appearing to benefit in terms of environmental attitudes and environmental locus of control from the gardening curriculum. Although other research has found similar differences in the past, perhaps these results indicate that future research should focus on the development of gardening curricula that target the needs and interests of boys or minorities. Past research has found that boys are interested in the 
garden and vegetation for play and adventure (Harvey, 1989). More research needs to explore these topics for boys and minority children.

\section{Literature cited}

Alexander, J., M. North, and D. Hendren. 1995. Master Gardener classroom garden project: An evaluation of the benefits to children. Children's Environ. 12(2):123133.

Bunting, T.E. and L.R. Cousins. 1983. Development and application of the “Children's Environmental Response Inventory." J. Environ. Educ. 15(1):5-10.

Bunting, T.E. and L.R. Cousins. 1985. Environmental dispositions among school-age children. Environ. Behav. 17:725-768.

Cammack, C., T.M. Waliczek, and J.M. Zajicek. 2002a. The Green Brigade: The effects of a community-based horticultural program on the horticultural knowledge and environmental attitude of juvenile offenders. HortTechnology 12(1):77-81.

Cammack, C., T.M. Waliczek, and J.M. Zajicek. 2002b. The Green Brigade: The effects of a community-based horticultural program on the self-development characteristics of juvenile offenders. HortTechnology 12:82-86.

Caro, V. and A. Ewert. 1995. The influence of acculturation on environmental concerns: An exploratory study. J. Environ. Educ. 26(3):13-21.

Carson, R. 1962. Silent spring. Houghton Mifflin, Boston.

Cohen, S. and D. Horm-Wingerd. 1993. Children and the environment. Environ. Behav. 25(1):103-120.

Culen, G.R., H.R. Hungerford, A.N. Tomera, D.J. Sivek, M. Harrington, and M. Squillo. 1986. A comparison of environmental perceptions and behaviors of five discrete populations. J. Environ. Educ. 17(3):24-32.

Dewey, J.D. 1938. Experience and education. Macmillan, New York.

Disenger, J.L. 1998. Tensions in environmental education: Yesterday, today, tomorrow, p. 34-40. In: H.R. Hungerford, W.J. Blaum, T.L. Volk, and J.M. Ramsey (eds.). Essential readings in environmental education. Stipes, Champaign, IL.

Dressner, M. and M. Gill. 1994. Environmental education at summer nature camp. J. Environ. Educ. 25(3):35-41.

Eames-Sheavly, M. 1994. Exploring horticulture in human culture: An interdisci- plinary approach to youth education. HortTechnology 4(1):77-80.

Gall, M.D., W.R. Borg, and J.P. Gall. 1996. Educational research: An introduction. 6th ed. Longman, White Plains, NY.

Gigliotti, L.M. 1992. Environmental attitudes: 20 years of change? J. Environ. Educ. 24(1):15-25.

Ham, S.H., H. Rellergert-Taylor, and E.E. Krumpe. 1987. Reducing barriers to environmental education. J. Environ. Educ. 19(2):25-33.

Ham, S.H. and D.R. Sewing. 1987. Barriers to environmental education. J. Environ. Educ. 19(2):17-24.

Hart, R. 1977. Children's experience of place. Irvington Publishers, Halsted Press, New York.

Harvey, M. 1989. Children's experiences with vegetation. Children's Environ. Quarterly 8(1):36-43.

Hines, J., H. Hungerford, and A. Tomera. 1987. Analysis and synthesis of research on responsible environmental behavior: A meta-analysis. J. Environ. Educ. 18(2):1-8.

Howell, D.L. and J.R. Warmbrod. 1974. Developing student attitudes toward environmental protection. J. Environ. Educ. 5(4):29-30.

Hudson, S. 2001. Challenges for environmental education: Issues and ideas for the 2lst century. Bioscience 51(4):283-288.

Hungerford, H.R. and T.L. Volk. 1990. Changing learner behavior through environmental education. J. Environ. Educ. 21(3):8-22.

James, W.H. and J.B. Rotter. 1958. Partial and 100 percent reinforcement under chance and skill conditions. J. Exp. Psychol. 55:397-403.

Jaus, H.H. 1982. The effect of environmental education instruction on children's attitudes toward the environment. Sci. Educ. 66(5):689-692.

Kellert, S.R. 1985. Attitudes toward animals: Age-related development among children. J. Environ. Educ. 16(3):29-38.

Klemmer, C.D., T.M. Waliczek, and J.M. Zajicek. 2005. Growing minds: The effect of a school gardening program on the science achievement of elementary students. HortTechnology 15(3):448-452.

Knapp, C.E. 1972. Attitudes and values in environmental education. J. Environ. Educ. 3(4):26-29.

Krause, D. 1993. Environmental consciousness: An empirical study. Environ. Behav. 25(1):126-142.
Leeming, F.C., B.E. Porter, W.O. Dwyer, M.K. Cobern, and D.P. Oliver. 1997. Effects of participation in class activities on children's environmental attitudes and knowledge. J. Environ. Educ. 28(4):33-42.

Lefcourt, H.M. 1976. Locus of control: Current trends in theory and research. Lawrence Erlbaum Association, Hillsdale, NJ.

Lieberman, G. and L. Hoody. 1998. Closing the achievement gap: Using the environment as an integrating context for learning. State education and environment roundtable. Science Wizards, Poway, CA.

Likert, R. 1967. The method of constructing an attitude scale, p. 90-95. In: M. Fishbein (ed.). Readings in attitude theory and measurement. Wiley, New York.

Lineberger, S. and J. Zajicek. 2000. School gardens: Can a hands-on teaching tool affect students' attitudes and behaviors regarding fruit and vegetables? HortTechnology 10(3):593-597.

Newhouse, N. 1991. Implications of attitude and behavior research for environmental conservation. J. Environ. Educ. 22(1):26-32.

Ornstein, A.C. and F.P. Hunkins. 1998. Curriculum: Foundations, principles and issues. 3rd ed. Allyn and Bacon, Needham Heights, MA.

Pale, P.E., K.F. Thompson, and M. Keyes. 2001. Students, standards, and exploration: A responsive, relevant, and engaging curriculum. Middle School J. 33(1):3540 .

Palmberg, I. and J. Kuru. 2000. Outdoor activities as a basis for environmental responsibility. J. Environ. Educ. 31(4): 32-36.

Pigg, A.E., T.M. Waliczek, and J.M. Zajicek. 2006. Effects of a gardening program on the academic progress of third, fourth, and fifth grade math and science students. HortTechnology 16(2):262-264.

Ramsey, J. 1997. Comparing four environmental problem-solving modes, $\mathrm{p}$. 54-68. In: H.R. Hungerford, W.J. Blaum, T.L. Volk, and J.M. Ramsey (eds.). Essential readings in environmental education. Stipes, Champaign, IL.

Ramsey, J.M. 1993. The effects of issue investigation and action training on eighth-grade students' environmental behavior. J. Environ. Educ. 24(3):31-36.

Ramsey, J.M., H.R. Hungerford, and T.L. Volk. 1992. Environmental education in the K-12 curriculum: Finding a niche. J. Environ. Educ. 23(2):35-45. 
Ravitch, D. 2000. Left back: A century of failed school reforms. Simon \& Schuster, New York.

Rowe, M.B. 1973. Teaching science as continuous inquiry. McGraw Hill, New York.

Sheppard, J.A. 1995. The black-white environmental concern gap: An examination of environmental paradigms. J. Environ. Educ. 26(2):24-35.

Shin, D. 2000. Environmental education course development for preservice secondary school science teachers in the
Republic of Korea. J. Environ. Educ. 31(4):11-18.

Skelly, S.M. and J.M. Zajicek. 1998. The effect of an interdisciplinary garden program on the environmental attitudes of elementary school students. HortTechnology 8(4):579-583.

Smith-Sebasto, N.J. 1992. The revised perceived environmental control measure: A review and analysis. J. Environ. Educ. $23(2): 24-33$.

Texas Cooperative Extension Service. 1999. Junior Master Gardener Level 1 teacher/leader guide. Texas A\&M Agriculture Communications, College Station.

Waliczek, T.M. and J.M. Zajicek. 1999. School gardening: Improving environmental attitudes of children through hands-on learning. J. Environ. Hort. 17(4):180-184.

Wilson, R.A. and J. Smith. 1996. Environmental education and the education literature. J. Environ. Educ. 27(2):4042 . 